OmniAkuatika, $12(1): 73-80,2016$
ISSN: 1858-3873 print / 2476-9347 online
Research Article

\title{
Analisa Spasial Luas Tutupan Lamun di Pulau Tunda Serang, Banten
}

\author{
Nunung Noer Aziizah ${ }^{1^{\star}}$, Vincentius Paulus Siregar ${ }^{2}$, Syamsul Bahri Agus ${ }^{2}$, Agnestesya Manuputty ${ }^{1}$ \\ ${ }^{1}$ Mahasiswa Program Studi Teknologi Kelautan, Sekolah Pascasarjana IPB \\ ${ }^{2}$ Departemen IImu dan Teknologi Kelautan, Institut Pertanian Bogor, Bogor \\ Gedung Marine Center Lantai 3, Jalan Rasamala FPIK-IPB Bogor 16680 \\ Corresponding author : nunungnoeraziizah@yahoo.com
}

\begin{abstract}
ABSTRAK
Fungsi ekologis ekosistem lamun ialah sebagai produsen primer, pendaur unsur hara, penstabil dasar perairan, sebagai habitat tempat pemijahan (spawning ground), tempat pengasuhan (nursery ground) dan tempat mencari makan (feeding ground). Dewasa ini ekosistem lamun pada lingkungan pesisir telah banyak mengalami gangguan dan ancaman baik secara alami maupun oleh aktivitas manusia, diperlukan kajian mengetahui luasan tutupan lamun secara menyeluruh pada suatu pulau. Luas tutupan lamun dapat diketahui secara spasial melalui analisis citra satelit. Tujuan dari kajian ini adalah untuk mengetahui luasan dan persen penutupan lamun secara spasial yang ada di Pulau Tunda. Analisis citra satelit dilakukan dengan melakukan training area terhadap lamun dan klasifikasi menggunakan metode supervised classification dengan algoritma Support Vector Machine (SVM). Proses identifikasi jenis lamun dilakukan dengan menggunakan metode seagrass watch. Pengukuran kualitas air dilakukan secara in situ dan analisis laboratorium. Berdasarkan observasi langsung dilapangan, jenis lamun yang terdapat di Pulau Tunda ialah Enhalus acoroides, Cymodocea rotundata, Cymodocea Serrulata, Thalassia Hemprichii, dan Halophila ovalis. Berdasarkan analisis citra satelit didapatkan total luasan lamun di Pulau Tunda yaitu $11.14 \mathrm{Ha}$ dengan $0.004 \mathrm{Ha}$ untuk lamun jarang, $0.235 \mathrm{Ha}$ untuk lamun sedang, $0.015 \mathrm{Ha}$ untuk lamun padat dan $10.886 \mathrm{Ha}$ untuk lamun sangat padat, berdasarkan kriteria baku Kepmen LH 200 tahun 2004, lamun yang berada di Pulau Tunda termasuk dalam kategori kaya atau sehat $(>60 \%)$. Berdasarkan hasil yang diperoleh, terlihat bahwa analisis citra satelit mampu untuk menghitung persentase tutupan lamun dan menjadi informasi yang sangat berguna dalam analisis serta kajian kelestarian lamun yang berkelanjutan.
\end{abstract}

Kata kunci: lamun, analisis spasial, citra satelit, persen tutupan

\section{Pendahuluan}

Lamun merupakan tumbuhan berbunga (Angiospermae) yang hidup dan tumbuh terbenam di lingkungan laut, memiliki pembuluh, akar rimpang (rhizome), serta mampu berkembang secara generatif melalui pembentukan bunga dan benih (biji), maupun secara vegetatif melalui perpanjangan akar rimpang (Azkab, 2000). Secara morfologis, tumbuhan lamun mempunyai bentuk yang hampir sama, terdiri dari akar, batang, dan daun. Morfologi daun umumnya memanjang, kecuali jenis Halophila memiliki bentuk daun lonjong. Secara global luas padang lamun yang terdapat di perairan Indonesia mencapai sekitar 30.000 $\mathrm{km}^{2}$. Padang lamun mengalami degradasi yang diakibatkan oleh: (1) pengaruh pasang surut yang dapat menyebabkan tereksposenya lamun, (2) arus run off dari daratan dan hempasan gelombang laut menyebabkan pengendapan sedimen yang berlebihan dan erosi/abrasi, dan (3) ancaman terbesar berasal dari aktivitas manusia seperti penambangan pasir, baik di sungai maupun di laut serta pemakaian alat tangkap ikan yang tidak ramah lingkungan (Orth et al. 2006). Peran lamun dalam ekologi kawasan pesisir yaitu sebagai habitat berbagai biota laut termasuk menjadi tempat mencari makan (feeding ground) (Bortone, 2000). Peran lain dari padang lamun adalah sebagai pendaur zat hara, menstabilkan dan menahan sedimen yang dibawa oleh arus dan gelombang. Selain manfaat tersebut, dalam beberapa tahun terakhir 
ini peran padang lamun sebagai salah satu penyerap emisi karbon di perairan laut mulai diteliti (Duarte et al., 2010, Kiswara 2010). Teknologi satelit penginderaan jauh (remote sensing) memiliki kemampuan merekam data dan informasi secara luas, berulang dan lebih terinci mendeteksi perubahan ekosistem (Mumby 2006). Penelitian mengenai pemetaan dan monitoring ekosistem perairan dangkal (karang, mangrove dan lamun) banyak dilakukan dengan menggunakan teknologi penginderaan jauh dan analisis spektral citra satelit (Siregar, 2010, Supriyadi, 2010, Siregar et al., 2013). Pemantauan perkembangan padang lamun merupakan salah satu dasar dari kegiatan pengelolaan lingkungan pesisir. Penggunaan teknologi penginderaan jarak jauh (remote sensing). Metode konvensional (metode survei in-situ) untuk pemetaan padang lamun, secara spasial tidak akan lebih efektif dibandingkan dengan teknologi penginderaan jarak jauh (Hoczkovich dan Atkinson, 2003). Tujuan dari penelitian ini adalah memetakan sebaran lamun dengan pemanfaatan teknologi penginderaan jauh untuk mengetahui luas dan kerapatan lamun.

\section{Metodologi}

\subsection{Lokasi penelitian}

Penelitian dilaksanakan di ekosistem lamun Pulau Tunda, Provinsi Banten (Gambar 1).

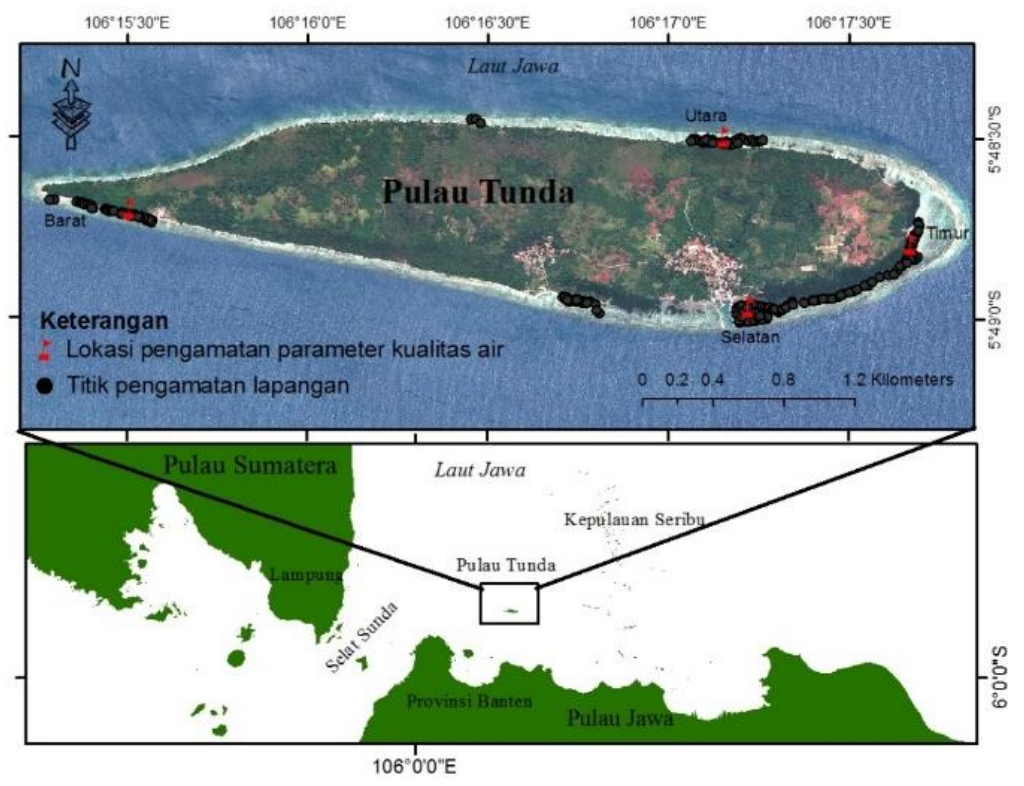

Gambar 1 Lokasi penelitian (Citra WorldView-2 2013)

Peralatan dalam penelitian dapat dikategorikan menjadi dua peruntukan: (1) Pengolahan data, terdiri dari seperangkat komputer yang didukung oleh beberapa piranti lunak pengolahan citra satelit dan analisis spasial. (2) Peralatan pengamatan lapangan, terdiri dari: perangkat navigasi berupa Global Positioning System (GPS) Trimble Juno 3D, transek $1 \times 1 \mathrm{~m}$, kamera fujifilm finepix XP70. Bahan penelitian yang digunakan dikategorikan menjadi tiga, (1) data spasial yang terdiri dari data vektor berupa Peta Rupa Bumi Indonesia skala 1:25.000 dari Badan Informasi Geospasial tahun 1999 dan data raster berupa citra satelit WorldView-2, (2) data atribut merupakan data hasil pengukuran di lapangan yang telah ditabulasikan, dan (3) lamun yang terdapat di Pulau Tunda. Karakteristik sensor pada citra satelit WorldView-2 berdasarkan (Digital Globe 2009) terdiri dari orbit satelit berada pada ketinggian $770 \mathrm{~km}$, tipe orbit sun synchronous merekam setiap jam 10.30 pagi. Resolusi temporal mencapai 1.1 hari dengan jumlah saluran multispektral sebanyak 8 saluran dan pankromatik. Saluran multispektral terdiri dari biru pantai $(400-450 \mathrm{~nm})$, biru $(450-510 \mathrm{~nm})$, hijau $(510-580 \mathrm{~nm})$, kuning $(585-625 \mathrm{~nm})$ merah $(630-690 \mathrm{~nm})$, merah tepi (705 - 769 $\mathrm{nm})$, inframerah-dekat1 $(770-895 \mathrm{~nm})$, inframerah-dekat2 (895 - $1040 \mathrm{~nm}$ ) (Wolf 2012). 
Resolusi spasial mencapai $1.85 \mathrm{~m}^{2}$ untuk saluran multispektral dan 0.46 untuk pankromatik. Resolusi radiometrik 16 bit dan tanggal akuisisi adalah 25 Agustus 2013 dengan format GeoTIFF, proyeksi Universal Transverse Mercator (UTM). 2.2. Metode pengamatan tutupan lamun
Persen penutupan lamun dapat ditentukan menggunakan transek berukuran $1 \times 1 \mathrm{~m}$ (Gambar 2) dengan metode seagrass watch mengacu pada (McKenzie et al. 2001), hasil pengukuran dan pengamatan lamun selanjutnya ditabulasikan.

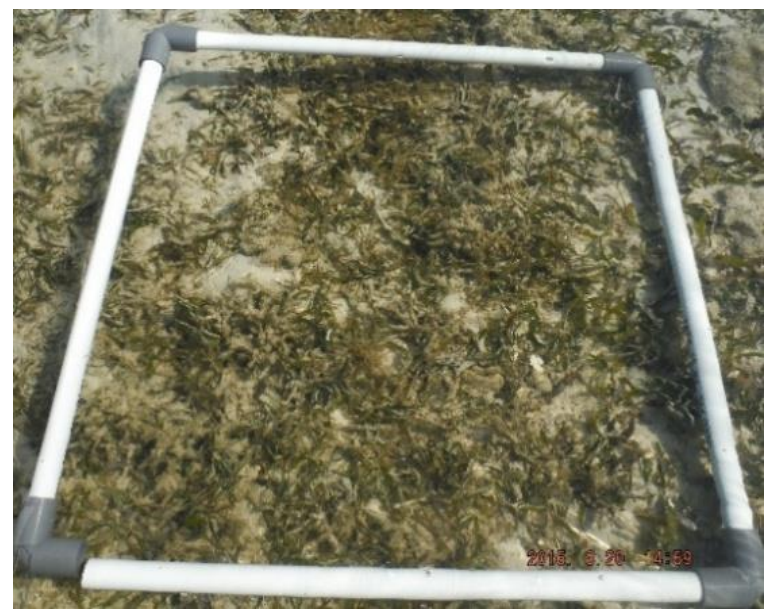

Gambar 2 Transek pengamatan lamun

Jenis substrat diamati dari setiap titik sampling meliputi: tipe substrat (pasir, lumpur, pasir-berlumpur, lumpur berpasir, pecahan karang, dan sebagainya). Parameter yang diukur langsung meliputi: suhu menggunakan termometer, salinitas menggunakan handrefraktometer, dan kedalaman diukur menggunakan rol meter.

\subsection{Pengelohan citra satelit}

Citra satelit yang digunakan telah terkoreksi geometrik dan memiliki acuan sistem koordinat. Proses pra pengolahan citra bertujuan untuk meningkatkan kualitas citra melalui koreksi atmosferik. Koreksi atmosferik dengan perangkat lunak pengolahan citra menggunakan modul Fast Line-of-sight Atmospheric Analysis of Spectral Hypercube (FLAASH) (Felde et al. 2003). FLAASH yang bekerja dengan kode Moderate Resolution Atmospheric Transmission (MODTRAN4) dapat menganalisis pengaruh atmosfer dari saluran tampak hingga inframerah pada citra multispektral (Felde et al. 2003). Parameter FLAASH yang digunakan terdiri dari file input dan output FLAASH, karakteristik sensor yang digunakan dan model atmosfer. Parameter FLAASH lanjutan terdiri dari model atmosfer tropical, model aerosol maritim, dan jarak pandang $40 \mathrm{~m}$.
Pengolahan awal klasifikasi yaitu proses segmentasi terhadap Input Image Layer (IIL) yang merupakan saluran multispektral citra WorldView-2 (coastal, blue, green, yellow, red, red-edge, NIR-1 dan NIR-2). Metode klasifikasi berbasis piksel sebelumnya memiliki kelemahan yaitu banyak mengabaikan hubungan spasial. Untuk mengatasi kelemahan ini, segmentasi digunakan dengan tujuan mengelompokkan informasi dalam piksel yang bersifat homogen. Segmentasi merupakan proses yang sama dengan deliniasi poligon untuk sampel klasifikasi.

\subsection{Depth invarian index (DII)}

Pendekatan sederhana berbasis citra untuk mengkompensasi pengaruh variabel kedalaman dalam pemetaan dasar perairan dikenal dengan teknik koreksi kolom perairan (Lyzenga, 1981). Besaran reflektansi objek dasar perairan pada citra :

$$
K i K j=\mathrm{a}+\sqrt{ }\left(\mathrm{a}^{\wedge} 2+1\right)
$$

Dimana :

$\mathrm{a}=(\sigma \mathrm{ii}-\sigma \mathrm{jj}) / 2 \sigma \mathrm{ij}$

$\mathrm{Ki} / \mathrm{Kj}$ merupakan rasio koefisien atenuasi dari dua panjang gelombang pada citra satelit, oii adalah variance dari pengukuran $\mathrm{Xi}$, $\sigma \mathrm{jj}$ adalah variance dari pengukuran $x j$ dan $\sigma \mathrm{ij}$ adalah 
covariance $\mathrm{xi}$ dan $\mathrm{xj}$. DIl dihitung dengan persamaan:

DIlij $=\log (x i)-[K i K j * \log x j]$

Koreksi kolom perairan dilakukan dengan menghitung rasio saluran pada citra untuk menghasilkan citra dengan 15 pasang saluran hasil transformasi 8 saluran.

\subsection{Klasifikasi supervised}

\section{Algoritma support vector machine (SVM)}

Algoritma SVM merupakan klasifikasi terbimbing yang dapat mencari sebuah vector atau garis sebagai pemisah dua kelas dengan memaksimalkan jarak antar kelas tersebut (Zhu and Blumberg 2002). Metode klasifikasi dibuat dengan terlebih dahulu mengidentifikasi piksel dengan membuat ROI (Region of Interest). ROI merupakan proses identifikasi data vektor hasil survei menjadi data raster (Indarto 2014). Metode SVM digunakan dalam menentukan kesamaan spektral pada piksel citra satelit berdasarkan training area yang dibuat (Karatzoglou A and Kurt 2006). Klasifikasi SVM menghasilkan kelas lamun dan non lamun yarng merupakan gambaran awal klasifikasi lamun secara umum. Optimasi klasifikasi SVM dalam penelitian ini dilakukan dengan transformasi saluran menggunakan koreksi kolom air untuk meningkatkan akurasi pemetaan lamun.

\section{Hasil dan Pembahasan}

\subsection{Ekosistem lamun di pulau Tunda}

Terdapat lima jenis lamun di lokasi penelitian yakni Enhalus acoroides, Cymodocea rotundata, Cymodocea Serrulata, Thalassia Hemprichi, dan Halophila ovalis. Masing-masing jenis memiliki karakteristik berbeda dijelaskan pada Lampiran 3 dan dapat dilihat pada Gambar 3.
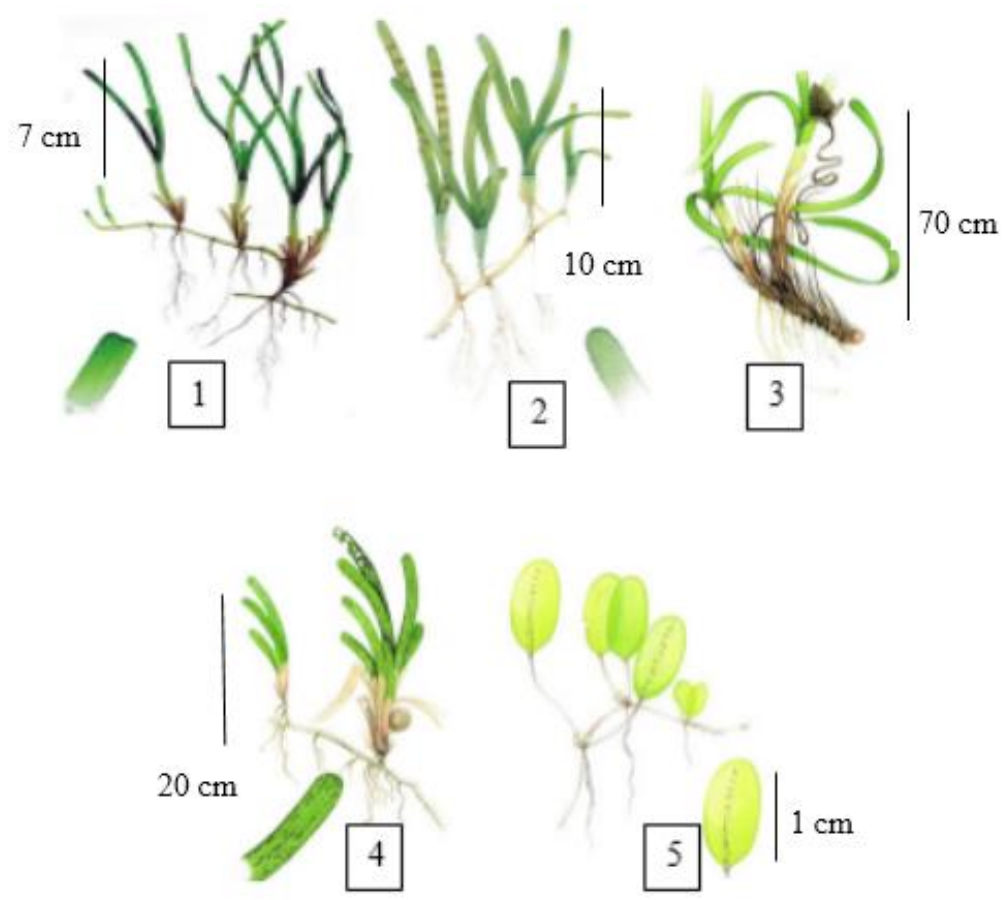

Gambar 3 Jenis lamun yang ditemukan di Pulau Tunda (1) C. rotundata, (2) C. serrulata, (3) E. acoroides, (4) T. hemprichii, dan (5) H. ovalis (McKenzie et al., 2001)

Lamun yang dominan di Pulau Tunda adalah jenis $T$. hemprichii dan E. acoroides, disebabkan karena kedua jenis tersebut memiliki toleransi untuk perubahan suhu, salinitas dan jenis substrat lebih luas dibanding jenis lainnya (Poedjirahajoe et al. 2013). Parameter kualitas perairan, jenis substrat, dan kondisi keawanan di ekosistem lamun Pulau Tunda dapat dilihat pada Tabel 1. Pertumbuhan lamun dapat dilihat dari pertambahan panjang daun dan rhizoma dalam kurun waktu tertentu. Pertumbuhan lamun sangat dipengaruhi oleh faktor-faktor internal 
seperti fisiologi, metabolisme dan faktor eksternal seperti zat-zat hara, tingkat kesuburan substrat, dan faktor lingkungan lainnya. Pertambahan luasan lamun tidak mengalami perubahan signifikan jika perairan dalam kondisi optimal (Christon et al., 2012).

Beberapa penelitian menyebutkan bahwa pada kisaran suhu $25-30^{\circ} \mathrm{C}$ terjadi fotosintesis yang optimal, terdapat pengaruh nyata dari perubahan suhu yaitu mempengaruhi metabolisme, penyerapan unsur hara dan kelangsungan hidup (Marsh et al., 1986, Bulthuis, 1987). Suhu yang diperoleh dilokasi penelitian (Tabel 1) termasuk dalam kisaran suhu yang sesuai untuk kehidupan lamun dan dapat melakukan fotosintesis dengan sempurna. Faktor lain yang mempengaruhi kehidupan lamun adalah salinitas. Lamun memiliki kemampuan toleransi yang berbeda terhadap salinitas, namun sebagian besar toleran pada kisaran 10-40\%. Salinitas optimum untuk lamun adalah 35\%o (Tomascik, 1997). Salinitas perairan di Pulau Tunda masih dalam batas toleran untuk kehidupan lamun meskipun bukan salinitas yang optimum.

Tabel 1 Parameter kualitas perairan, jenis substrat, dan kondisi keawanan

\begin{tabular}{|c|c|c|c|c|c|c|}
\hline Lokasi & $\begin{array}{c}\text { Suhu } \\
\text { rata - } \\
\text { rata }\left({ }^{\circ} \mathrm{C}\right)\end{array}$ & $\begin{array}{c}\text { Salinitas } \\
(\% \circ)\end{array}$ & $\mathrm{TSS}\left(\mathrm{mg} / \mathrm{L}^{-1}\right)$ & Substrat & $\begin{array}{c}\text { Tutupan } \\
\text { awan }\end{array}$ & $\begin{array}{c}\text { Kategori } \\
\text { cuaca }\end{array}$ \\
\hline Timur & 29 & 30 & 0.118 & $\begin{array}{c}\text { Pasir } \\
\text { berlumpur }\end{array}$ & $0 / 10$ & Cerah \\
\hline Utara & 30 & 31 & 0.11 & $\begin{array}{c}\text { Pecahan } \\
\text { karang } \\
\text { berpasir }\end{array}$ & $1.2 / 10$ & Cerah \\
\hline Selatan & 29 & 30 & 0.083 & $\begin{array}{c}\text { Pecahan } \\
\text { karang } \\
\text { berpasir }\end{array}$ & $1 / 10$ & Cerah \\
\hline Barat & 29 & 30 & 0.083 & Pasir & $2.3 / 10$ & $\begin{array}{c}\text { Cerah } \\
\text { berawan }\end{array}$ \\
\hline
\end{tabular}

Kekeruhan secara tidak langsung dapat mempengaruhi kehidupan lamun karena dapat menghalangi penetrasi cahaya yang dibutuhkan oleh lamun untuk berfotosintesis. Kekeruhan dapat disebabkan oleh adanya partikel-partikel tersuspensi, baik plankton maupun partikel mati seperti bahan organik, sedimen dan sebagainya (Hutomo dan Moosa, 2005). Menurut Kepmen L H (2004) tentang Baku Mutu Air Laut, perairan dengan nilai TSS $<20 \mathrm{mg} / \mathrm{L}$ termasuk dalam kategori rendah, sehingga perairan Pulau Tunda memiliki kondisi yang jernih dengan penetrasi cahaya ke dalam air cukup baik.

Respon spektral yang dihasilkan suatu lamun tidak akan optimal jika dalam wilayah tersebut tidak terdapat cahaya matahari akibat adanya tutupan awan. Optimalnya cahaya matahari bersinar dapat diketahui berdasarkan kondisi tutupan awan. Pulau Tunda memiliki kondisi tutupan awan selama pengamatan lapangan masih termasuk dalam kategori sangat sedikit dan dapat dikatakan cahaya matahari dalam kondisi optimal (BMKG Serang, 2015). Kondisi cuaca yang cerah dengan tutupan awan rendah menghasilkan radiasi energi matahari maksimum. Energi matahari berpengaruh terhadap reflektansi lamun. Radiasi energi matahari yang mengenai lamun dapat diserap dan dipantulkan kembali berupa reflektansi yang menggambarkan karakteristik lamun secara optimal (Adriat, 2015).

\subsection{Klasifikasi SVM}

Koreksi kolom perairan dilakukan untuk mengurangi hambatan dalam memprediksi reflektansi dasar perairan (Lyzenga, 1981). Hasil klasifikasi dengan algoritma SVM terhadap citra hasil transformasi DIl disajikan pada Gambar 4. 


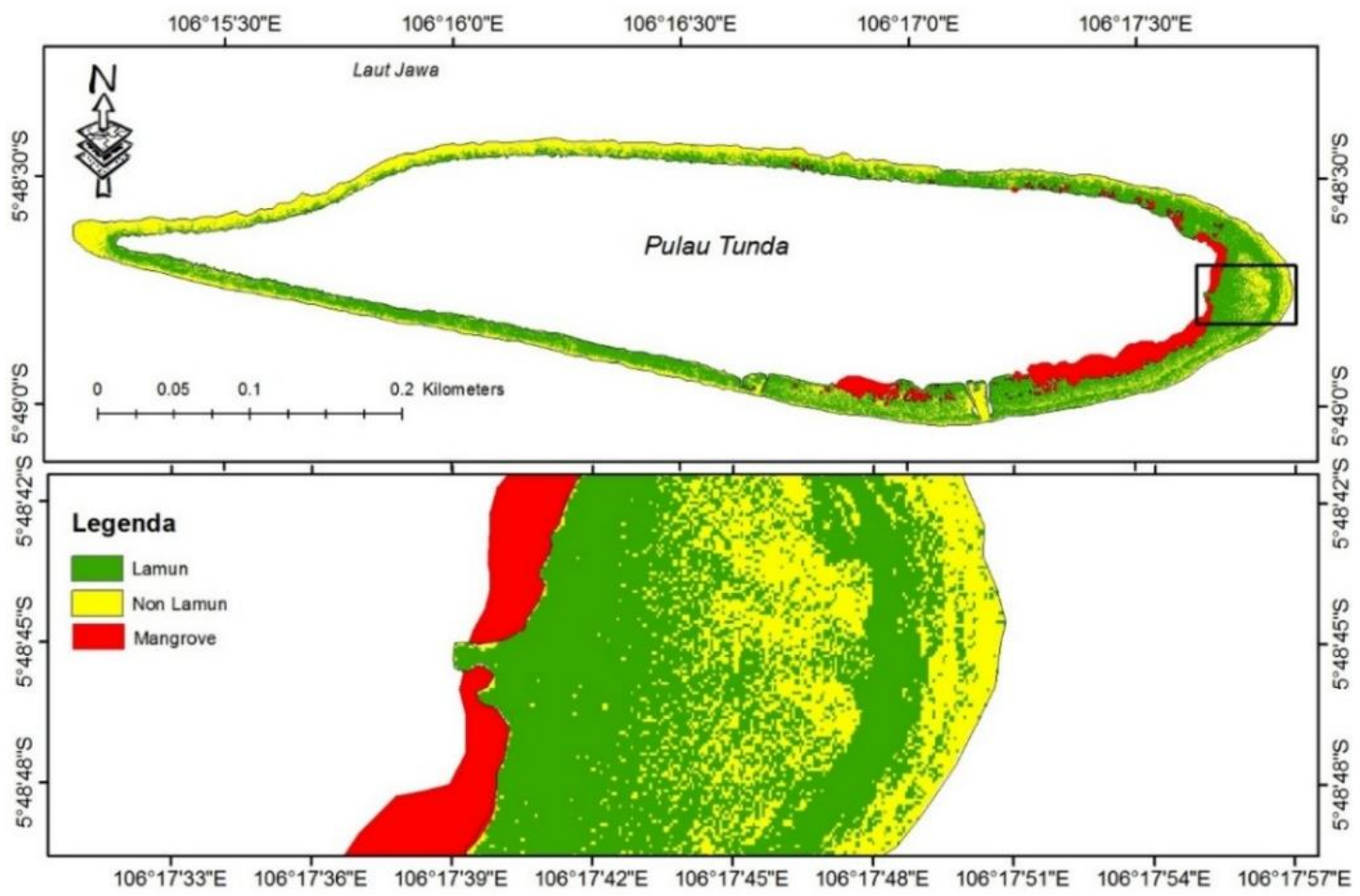

Gambar 4 Hasil klasifikasi SVM dengan koreksi DII

Hasil klasifikasi citra dengan transformasi saluran DII memiliki nilai akurasi secara keseluruhan sebesar $76.4 \%$. Akurasi yang dihasilkan menunjukan bahwa lamun mampu dipetakan dengan baik dengan citra terkoreksi kolom air. Hasil klasifikasi menunjukkan luas area masing-masing kelas adalah $50.7 \mathrm{Ha}$ untuk kelas lamun dan $34 \mathrm{Ha}$ untuk kelas non lamun. Hasil tersebut cukup mewakili kondisi di lapangan, karena kolom perairan yang dapat mengganggu penetrasi gelombang elektromagnetik telah terkoreksi.

Aplikasi penginderaan jauh dapat memetakan lamun hingga kerapatan dengan pendekatan nilai spektral pada piksel citra. Hasil klasifikasi berdasarkan kerapatan lamun ditunjukkan pada Gambar 5. Lamun diklasifikasi menjadi kelas Lamun Jarang (LJ), Lamun Sedang (LS), Lamun Padat (LP), Lamun Sangat Padat (LSP). 

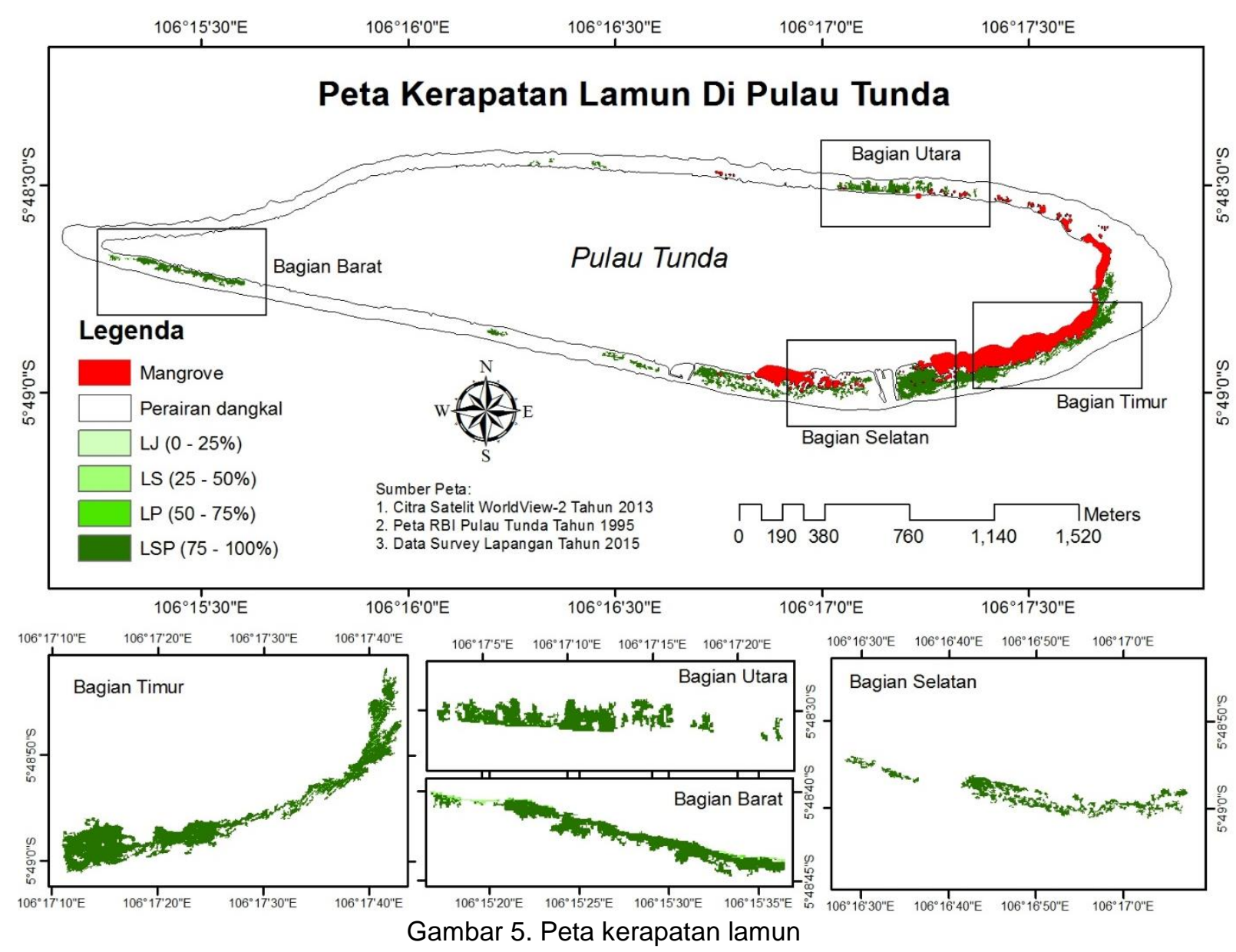

Hasil analisis nilai reflektansi dari citra satelit, diketahui lamun di pulau Tunda didominasi kelas LSP. Berdasarkan kriteria baku Kepmen LH 200 tahun 2004, lamun yang berada di Pulau Tunda termasuk dalam kategori kaya atau sehat $(>60 \%)$. Nilai reflektansi pada citra akan dikelaskan dengan data pengamatan lamun di lapangan. Berdasarkan hasil yang diperoleh, terlihat bahwa analisis citra satelit mampu untuk menghitung persentase tutupan lamun dan menjadi informasi yang sangat berguna dalam analisis serta kajian kelestarian lamun yang berkelanjutan.

\section{Kesimpulan}

Lamun yang dominan di Pulau Tunda adalah jenis $T$. hemprichii dan $E$. acoroides. Hasil klasifikasi citra menunjukkan luas area masing-masing kelas adalah $50.7 \mathrm{Ha}$ untuk kelas lamun dan $34 \mathrm{Ha}$ untuk kelas non lamun. Analisis kerapatan lamun berdasarkan reflektansi citra satelit didominasi kelas LSP. Analisis citra satelit mampu untuk menghitung persentase tutupan lamun dan menjadi informasi yang sangat berguna dalam analisis serta kajian kelestarian lamun yang berkelanjutan.

\section{Daftar Pustaka}

Adriat, R. 2015. Keterkaitan variasi sinar kosmik dengan tutupan awan. Positron 5 (1), 4857.

Azkab, M.H. 2000. Struktur dan fungsi pada komunitas lamun. Oseana 3 (25): 9-17.

Bortone, S.A. 2000. Seagrasses: Monitoring, ecology, physiology, and management. CRC Press.

Bulthuis, D.A. 1987. Effects of temperature on photosynthesis and growth of seagrasses. Aquatic Botany 27 (1), 2740.

Christon., Djunaedi, O. S., Purba, N.P. 2012. Pengaruh tinggi pasang surut terhadap pertumbuhan dan biomassa daun lamun Enhalus acoroides di pulau pari 
kepulauan seribu jakarta Jurnal Perikanan dan Kelautan 3 (3): 287-294.

Digital Globe. 2009. The benefits of the 8 spectral bands of worldview-2. Pages 12 : White Paper.

Duarte, C.M, Marbà, N., Gacia, E., Fourqurean, J.W., Beggins, J., Barrón, C., Apostolaki, E.T. 2010. Seagrass community metabolism: Assessing the carbon sink capacity of seagrass meadows. Global Biogeochemical Cycles. 24 (4), 1-8.

Hutomo, M., Moosa, M.K. 2005. Indonesian marine and coastal biodiversity: Present status. Indian Journal of Marine Sciences 34 (1), 88-97.

Kepmen L H. 2004. Keputusan menteri negara lingkungan hidup no: 51 tahun 2004 tentang baku mutu air laut. Jakarta: Deputi Menteri Lingkungan Hidup: Bidang Kebijakan dan Kelembagaan LH

Kiswara, W. 2010. Studi pendahuluan: Potensi padang lamun sebagai karbon rosot dan penyerap karbon di pulau pari, teluk jakarta. LIPI 36 (3): 361-376.

Lyzenga, D.R. 1981. Remote sensing of bottom reflectance and water attenuation parameters in shallow water using aircraft and landsat data. International Journal of Remote Sensing 2 (1): 71-82.

Marsh, J.A., Dennison, W.C., Alberte, R.S. 1986. Effects of temperature on photosynthesis and respiration in eelgrass (Zostera marina I.). Journal of Experimental Marine Biology and Ecology 101 (3), 257-267.

McKenzie, L., Campbell, S., Roder, C. 2001. Seagrass-watch: Manual for mapping and monitoring seagrass resources by community (citizen) volunteers. QFS, NFC, Cairns.

Mumby, P.J. 2006. Connectivity of reef fish between mangroves and coral reefs: Algorithms for the design of marine reserves at seascape scales. Biological conservation 128 (2), 215-222.

Orth, R.J., Carruthers, T.J., Dennison, W.C., Duarte, C.M., Fourqurean, J.W., Heck, K.L., Hughes, A.R., Kendrick, G.A., Kenworthy, W.J., Olyarnik, S. 2006. A global crisis for seagrass ecosystems. Bioscienc. 56 (12), 987-996.
Poedjirahajoe, E., Mahayani, N.P.D., Sidharta, B.R., Salamuddin, M. 2013. Tutupan lamun dan kondisi ekosistemnya di kawasan pesisir madasanger, jelenga, dan maluk kabupaten sumbawa barat seagress coverage and ecosystem condition at the coastal area of madasanger, jelenga and maluk, west sumbawa. Jurnal Ilmu dan Teknologi Kelautan Tropis 5 (1): 36-46.

Siregar, V. 2010. Pemetaan substrat dasar perairan dangkal karang congkak dan lebar kepulauan seribu menggunakan citra satelit quickbird. Jurnal IImu dan Teknologi Kelautan Tropis 2 (1), 19-30.

Siregar, V., Wouthuyzen, S., Sunuddin, A., Anggoro, A., Mustika, A. 2013. Pemetaan habitat dasar dan estimasi stok ikan terumbu dengan citra satelit resolusi tinggi. Jurnal IImu dan Teknologi Kelautan Tropis 5 (2), 453-463.

Supriyadi, I.H. 2010. Pemetaan padang lamun di perairan teluk toli-toli dan pulau sekitarnya, sulawesi barat. Oseanologi dan Limnologi di Indonesi 2 (36), 147164.

Tomascik, T. 1997. The ecology of the indonesian seas. Oxford University Press.

Wolf, A.F. 2012. Using worldview-2 vis-nir multispectral imagery to support land mapping and feature extraction using normalized difference index ratios. Longmont, Colorado International Society for Optics and Photonics. 